\title{
Tenofovir veya Entekavir Tedavisi Alan Kronik Hepatit B Hastalarında Histolojik Yanıtların Değerlendirilmesi
}

\section{Evaluation of Histological Response in Chronic Hepatitis B Patients with Tenofovir or Entecavir Therapy}

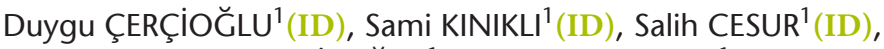

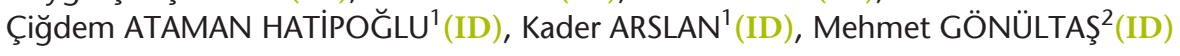 \\ ${ }_{1}^{1}$ Ankara Eğitim ve Araştırma Hastanesi, Enfeksiyon Hastalıkları ve Klinik Mikrobiyoloji Kliniği, Ankara. \\ ${ }^{1}$ Ankara Training and Research Hospital, Clinic of Infectious Diseases and Clinical Microbiology, Ankara, Turkey. \\ ${ }^{2}$ Ankara Eğitim ve Araştırma Hastanesi, Tıbbi Patoloji Kliniği, Ankara. \\ ${ }^{2}$ Ankara Training and Research Hospital, Clinic of Medical Pathology, Ankara, Turkey.
}

Makale Atıfı: Çerçioğlu D, Kınıklı S, Cesur S, Ataman Hatipoğlu Ç, Arslan K, Gönültaş M. Tenofovir veya entekavir tedavisi alan kronik hepatit B hastalarında histolojik yanıtların değerlendirilmesi. Mikrobiyol Bul 2020;54(1):95-109.

ÖZ

Kronik hepatit B (KHB), tüm dünyada ve Türkiye'de önemli bir halk sağlığı sorunudur. Çalışmanın amacı KHB tanısı ile tenofovir veya entekavir tedavisi alan hastalarda histolojik, virolojik, serolojik ve biyokimyasal yanıt düzeylerinin değerlendirilmesidir. Bu çalışmada, bir yıl veya daha fazla süre ile tenofovir veya entekavir tedavisi alan hastalara kontrol karaciğer biyopsisi yapılmıştır. Histopatolojik evreleme modifiye Knodell sistemine göre skorlanmıştır. Çalışmaya 56 tenofovir ve 31 entekavir tedavisi alan toplam 87 KHB hastası dahil edilmiştir. Her iki gruptaki hastaların tedavi öncesi parametreleri benzer bulunmuştur ( $p>0.05$ ). Tedavi sonunda her iki grupta HBV DNA, alanin aminotransferaz değerleri ve histolojik aktivite indeksi (HAi) skorları ortalamalarında anlamlı azalma görülmüştür ( $p=0.001)$; ancak fibrozis skorlarında istatistiksel olarak anlamlı değişiklik saptanmamıştır ( $p>0.05)$. Tenofovir grubunda \%66.1, entekavir grubunda \%54.8 oranında histolojik yanıt elde edilmiştir. Tenofovir alan hastaların \%12.5'inde, entekavir alan hastaların \%12.9'unda fibrozis skorlarında iyileşme görülmüştür. Tenofovir grubunda \%14.3, entekavir grubunda \%22.6 oranında fibrozis skorunda kötüleşme saptanmıştır. Tedavi başlangıcında fibrozis evresinin orta/ileri (İshak fibrozis skoru: 3-6) olması, histolojik yanıt sağlanmasında ve fibrozis skorunda iyileşmede (sırasıyla $\mathrm{OR}=3.99, \mathrm{p}=0.01 ; \mathrm{OR}=31.67, \mathrm{p}=0.002$ ); tedavi süresinin beş yıldan uzun olması nekroenflamatuvar skorda iyileşmede bağımsız belirleyici faktör olarak bulunmuştur $(O R=5.79, p=0.02)$. Tenofovir ve entekavir grupları arasında virolojik, serolojik, biyokimyasal ve histolojik yanıtlar ile HAi ve fibrozis skorlarında iyileşme açısından anlamlı fark saptanmamıştır ( $p>0.05$ ). KHB hastalarında tenofovir ve entekavir tedavileri ile benzer histolojik, virolojik, serolojik ve biyokimyasal yanıt elde edilmiştir. Antiviral tedavilerin karaciğer histolojisindeki iyileşmeye etkilerinin anlaşılabilmesi için uzun süreli tedavi alan, daha fazla sayıda hastayı kapsayan çalışmalara ihtiyaç olduğu düşüncesindeyiz.

Anahtar kelimeler: Kronik hepatit B; tenofovir; entekavir; histolojik yanit; nekroenflamatuvar skor; fibrozis skoru. 


\section{ABSTRACT}

Chronic hepatitis B (CHB) is an important public health problem in the world and Turkey. The aim of this study was to evaluate the histological, virological, serological and biochemical response rates in $\mathrm{CHB}$ patients receiving tenofovir or entecavir therapy. Control liver biopsies were performed on patients who received tenofovir or entecavir therapy for one year or longer. Histopathological grading was scored according to the modified Knodell system. Eighty-seven CHB patients were included in this study, 56 patients were receiving tenofovir and 31 patients were receiving entecavir therapy. Patients in two treatment groups were similar in terms of baseline parameters $(p>0.05)$. At the end of the treatment, there was a significant decrease in mean values of HBV DNA, alanine aminotransferase and necroinflammatory scores for both groups $(p<0.001)$; however, no statistically significant change was observed in fibrosis scores ( $p>0.05$ ). Histological responses were obtained $66.1 \%$ from the tenofovir group and $54.8 \%$ from the entecavir group. Treatment with tenofovir and entecavir resulted with improvement in Ishak fibrosis scores in $12.5 \%$ and $12.9 \%$ of the patients, respectively. For $14.3 \%$ of the tenofovir-treated patients and for $22.6 \%$ of the entecavir-treated patients, the Ishak fibrosis scores worsened. Baseline intermediate/ advanced fibrosis stage (Ishak fibrosis score: $3-6$ ) was found as independent determinant factor on histological response and improvement of fibrosis score $(\mathrm{OR}=3.99, \mathrm{p}=0.01 ; \mathrm{OR}=31.67, \mathrm{p}=0.002$; respectively) and treatment duration longer than five years is an independent determinant for improvement of necroinflammatory score $(\mathrm{OR}=5.79, \mathrm{p}=0.02)$. There was no significant difference in the virological, serological, biochemical and, histological responses and improvement of necroinflammatory and fibrosis scores between tenofovir and entecavir groups ( $p>0.05$ ). Similar histological, virological, serological and biochemical responses were obtained in patients with $\mathrm{CHB}$ receving tenofovir and entecavir treatments. Further studies involving a large number of patients receiving long-term therapy should be done to understand the effects of antiviral treatments on healing of liver histology.

Keywords: Chronic hepatitis B; tenofovir; entecavir; histological response; necroinflammatory score; fibrosis score.

\section{Giriş}

Dünyada 240 milyon insanın hepatit B virüsü (HBV) ile kronik olarak enfekte olduğu düşünülmektedir. Bu hastaların \%20 ila \%30'unda, majör komplikasyonlar olan siroz ve hepatoselüler karsinom (HSK) gelişmekte ve kronik hepatit B (KHB) nedeniyle yılda yaklaşık 650.000 ölüm meydana gelmektedir ${ }^{1}$. KHB hastalarında yüksek HBV DNA düzeylerinin siroz ve HSK gelişimi ile ilişkili olduğu gösterilmiştir ${ }^{2,3}$. KHB hastalarında tedavinin amacı, hastalığın progresyonuyla oluşabilecek siroz, karaciğer yetmezliği ve HSK gibi komplikasyonları önleyerek hastalığa bağlı mortalite ve morbiditeyi azaltmak, hastanın yaşam kalitesini ve süresini artırmaktır ${ }^{4}$. Bu amacın sağlanması için, tedavide ana hedef uzun dönem HBV DNA'sının baskılanmasıdır. Tedavi ile viral baskılama birlikte histolojik iyileşme de sağlayabilmektedir ${ }^{4-6}$. Yapılan çalışmalarda KHB hastalarında antiviral tedavi ile histolojik iyileşme görüldüğü belirlenmiştir ${ }^{7-12}$. Nükleoz(t)it analoğu olan tenofovir disoproksil fumarat (DF) ve entekavir ilk basamak tedavide önerilen yüksek genetik bariyere sahip oral antiviral ilaçlardır ${ }^{5,6}$.

Bu çalışmada, en az bir yıl süre ile tenofovir DF veya entekavir tedavisi alan KHB hastalarında histolojik, virolojik, serolojik, biyokimyasal yanıtların karşılaştırılması ve histolojik iyileşmeye etki eden faktörlerin araştırılması amaçlanmışır. 


\section{GEREÇ ve YÖNTEM}

Bu çalışma, T.C. Sağlık Bakanlığı Türkiye Kamu Hastaneleri Kurumu Ankara Illi 1. Bölge Kamu Hastaneleri Sekreterliği, Ankara Numune Eğitim ve Araştırma Hastanesi Klinik Araştırmalar Etik Kurul Başkanlığı onayı ile gerçekleştirildi ve hastalardan onam alındı (Tarih: 26.04.2017 ve Karar no: E-17-1376/2017).

\section{Hasta Grubu}

Araştırmaya Ankara Eğitim ve Araştırma Hastanesi, Enfeksiyon Hastalıkları ve Klinik Mikrobiyoloji Kliniğine 01/09/2016-30/07/2017 tarihleri arasında kontrol için başvurmuş, KHB tanısı ile en az bir yıl süreyle tenofovir DF (300 mg/gün) veya entekavir (0.5 mg/gün) tedavisi alan, kontrol biyopsi yapılmasını kabul eden, 18 yaş üstündeki hepatit D virüsü (HDV), hepatit C virüsü (HCV) ve insan immün yetmezlik virüsü (HIV) enfeksiyonu bulunmayan 87 hasta dahil edildi.

\section{Değerlendirilen Değişkenler}

Hastaların yaş, cinsiyet gibi demografik verileri, tedavi deneyimli hastalarda daha önce almış oldukları antiviral ilaçlar ve tedavi değişikliği nedenleri kaydedildi.

Tedavi öncesinde yapılan biyopsiler ile kontrol biyopsilerindeki nekroenflamatuvar skorlar ve Ishak fibrozis skorları; tedavi başlangıcında, takibinde ve sonunda ölçülen aspartat aminotransferaz (AST) ve alanin aminotransferaz (ALT) değerleri, virolojik durumları (HBsAg, anti-HBs, HBeAg, anti-HBe) ve HBV DNA düzeyleri kaydedildi.

Serolojik testler (HBsAg, anti-HBs, HBeAg, anti-HBe) "enzyme linked immunosorbent assay (ELISA)" yöntemiyle Ankara Eğitim ve Araştırma Hastanesi, Tıbbi Mikrobiyoloji Kliniğinde çalışıldı. Karaciğer enzimleri (AST, ALT) değerleri ise Ankara Eğitim ve Araştırma Hastanesi Tıbbi Biyokimya Kliniğinde çalışıldı.

HBsAg, anti-HBs, HBeAg, anti-HBe testleri Roche Diagnostik/Cobas 6000 e601 analizatörü kullanılarak, ELISA yöntemi ile; HBV DNA testi Qiagen polimeraz zincir reaksiyonu (PCR) kiti (Artus Qiagen GmbH, Hilden, Almanya) kullanılarak çalışıldı.

Çalışmada hastaların HBV DNA PCR testleri hizmet satın alınarak moleküler testler laboratuvarında (Synlab, Ankara) gerçekleştirildi. Çalışmada DNA-RNA ekstraksiyonu tam otomatik izolasyon robotu QIASymphony (Artus Qiagen $\mathrm{GmbH}$, Hilden, Almanya) ile, gerçek zamanlı PCR (Rt-PCR) ise Rotor Gene Corbett R-6000 (Artus Qiagen GmbH, Hilden, Almanya) cihazı ile gerçekleştirildi. Testlerin çalışma, değerlendirme ve analitik duyarlılıklarının belirlenme aşamaları üretici firmanın tanımladığı standartlar doğrultusunda değerlendirildi. Testlerin çalışma ve değerlendirme aşamaları üretici firmanın tanımladığı standartlar doğrultusunda yapıldı. Kit üreticisinin kitapçı̆̆ında yöntemin analitik duyarlılık sınırı $10.2 \mathrm{IU} / \mathrm{ml}$, dinamik aralığı ise 31.6-2 $\times 10^{7} \mathrm{kopya} / \mathrm{ml}$ olarak belirtilmiştir ${ }^{13}$. Dış kalite kontrol referans panelleri için Instand (Almanya) ve Motakk (Türkiye) panelleri kullanıldı. 
Tedavi deneyimli hastaların virolojik yanıtlarının değerlendirilmesinde, tedavi ile virolojik baskılanma sağlanmış olup yan etki ve diğer nedenlerle antiviral ilaç değişikliği yapılmış olan hastalarda, çalışmaya virolojik baskılanmanın sağlandığı ilk tedavi verileri; virolojik yanıtsızlık/kırılma nedeni ile değişiklik yapılan hastalarda, yeni tedavi başlangıcındaki HBV DNA değerleri kullanıldı.

Patolojik incelemeler Ankara Eğitim ve Araştırma Hastanesi, Patoloji Kliniğinde aynı patolog tarafından yapıldı. Karaciğer biyopsi örneklerinin histopatolojik aktivite indeksi (nekroenflamatuvar skorlar) ve fibrozis evrelemesi modifiye Knodell skoru kullanılarak değerlendirildi. Nekroenflamatuvar skorlar; aktif hepatit yok (0), minimal (1-3), hafif (4-8), orta (9-12) ve şiddetli (13-18) kronik hepatit olarak gruplandırıldı. Ishak evrelemesinde fibrozis skoru 0, 1 ve 2 olanlar fibrozis yok/hafif fibrozis grubunu, fibrozis skoru 3, 4, 5 ve 6 olanlar orta/ileri fibrozis grubu olarak değerlendirildi.

Tenofovir DF ve entekavir gruplarında histolojik yanıt, nekroenflamasyon ve fibrozis skorlarındaki değişiklikler ile histolojik iyileşmeye etki edebilecek faktörler araştırıldı.

\section{Tedavi Yanıtları}

"European Association for the Study of the Liver (EASL)" 2017 rehberine göre fibrozis skorunda kötüleşme olmaksızın nekroenflamatuvar (HAi) skorda $\geq 2$ puan düzelme olması histolojik yanıt, HAi skorunda $\geq 2$ puan azalma nekroenflamatuvar skorda iyileşme, fibrozis skorunda $\geq 1$ puan azalma fibroziste iyileşme, $\geq 1$ puan artma fibroziste kötüleşme olarak kabul edildi. Virolojik yanıt, polimeraz zincir reaksiyonu ile saptanamayacak düzeyde HBV DNA bulunması olarak tanımlandı. Serolojik yanıt, tedavi sırasında HBeAg veya $\mathrm{HBsAg}$ 'nin kaybı ve serokonversiyon gelişmesi; biyokimyasal yanıt tedavi öncesi serum ALT değerleri yüksek olan hastalarda, tedaviyle ALT değerinin normal sınırlara gerilemesi olarak tanımlandı ${ }^{5}$. ALT için normal üst sınır (NÜS), 40 U/L olarak kabul edildi.

\section{İstatistiksel Analiz}

İstatistiksel analizler IBM SPSS versiyon 23.0 (Chicago, SPSS Inc.) programı ile yapıldı. Değişkenlerin normal dağılıma uygunluğu analitik yöntemler (Kolmogorov-Smirnov/ Shapiro-Wilk testleri) kullanılarak incelendi. Tanımlayıcı analizler, normal dağılıma uyan veriler için ortalama, normal dağılıma uymayan veriler için ise ortanca kullanılarak verildi. İstatistiksel değerlendirmede çapraz tablolar, normal dağılıma uyan değişkenlerde bağımsız gruplar T testi, normal dağılıma uymayanlarda ise Mann-Whitney $U$ ve Wilcoxon testleri kullanıldı. Çapraz tablolarda gruplar arasında fark, Ki-kare ve Fisher's exact testleri kullanılarak karşılaştırıldı. Önceki analizlerde tedavi sonucunu öngörmede belirlenen olası faktörlerin ( $p<0.3$ olanlar dahil edilmiştir), bağımsız prediktörler olup olmadığı; çok değişkenli analizde lojistik regresyon analizi kullanılarak incelendi. Model uyumu için Hosmer-Lemeshow testi kullanıldı. p değerinin $<0.05$ olduğu değerler istatistiksel olarak anlamlı kabul edildi. 


\section{BULGULAR}

Çalışmaya alınan 87 hastanın 56 (\%64)'sı tenofovir, 31 (\%36)'i entekavir tedavisi alan hastalardan oluşmuştur. Tenofovir grubunda 32 (\%57) hasta tedavi naif, 24 (\%43) hasta tedavi deneyimli [12 (\%50)'si lamivudin, 9 (\%37)'u telbivudin ve 3 (\%13)'ü entekavir deneyimli]; entekavir grubunda 18 (\%58) hasta tedavi naif ve 13 (\%42) hasta tedavi deneyimli [3 (\%23)'ü lamivudin, 10 (\%77)'u telbivudin deneyimli] hastalardan oluşmuştur.

Virolojik yanıtsızlık, kısmi virolojik yanıt veya virolojik kırılma nedeniyle önceki tedavileri değiştirilen hasta sayısı tenofovir grubunda 6 (\%25) olarak belirlenirken, entekavir grubunda bu nedenlerden dolayı tedavi değişikliği yapılan hasta gözlenmemiştir. Diğer hastaların tedavileri yan etki ve potent antiviral ilaçla tedavi isteği üzerine değiştirilmiştir.

Hastaların 39 (\%45)'u erkek, 48 (\%55)'i kadın olarak tespit edilmiştir. Hastaların yaş ortalaması $42.48 \pm 10.77 \mathrm{yll}$ (21-69) olarak belirlenmiştir. Tenofovir ve entekavir tedavisi alan hasta gruplarında yaş ortalamaları ve cinsiyet dağılımı açısından anlamlı fark bulunmamıştır ( $p>0.05$ ) (Tablo I).

Hastaların tedavi sürelerinin ortanca değerleri; tenofovir grubunda 23.5 (12-95), entekavir grubunda 24 (12-111) ay olarak belirlenmiştir. Tedavi deneyimli hastaların toplam tedavi sürelerinin ortanca değeri tenofovir grubunda 40 (14-115), entekavir grubunda 45 (14-111) ay olarak saptanmıştır. Gruplar arasında tedavi süreleri ortalamalarında istatistiksel olarak anlamlı fark saptanmamıştır ( $p>0.05)$ (Tablo I).

\begin{tabular}{|c|c|c|c|c|}
\hline & & $\begin{array}{c}\text { Tenofovir } \\
(\mathrm{n}=56)\end{array}$ & $\begin{array}{l}\text { Entekavir } \\
(\mathrm{n}=31)\end{array}$ & $\mathbf{p}$ \\
\hline Yaş & $(y \mathrm{ll})^{*}$ & $42.73 \pm 10.8$ & $42.03 \pm 10.7$ & 0.91 \\
\hline Cinsiyet (erkek) & n (\%) & $28(50)$ & $11(35.5)$ & 0.19 \\
\hline Mevcut tedavi süresi & $A y^{* *}$ (aralık) & $23.5(12-95)$ & $24(12-111)$ & 0.56 \\
\hline \multirow[t]{2}{*}{ Toplam tedavi süresi } & $A y^{* *}$ (aralık) & $40(14-115)$ & $45(14-111)$ & 0.37 \\
\hline & TÖ & $12(21.4)$ & $6(19.4)$ & 0.81 \\
\hline HBeAg pozitifliği & TS & $8(14.3)$ & $3(9.7)$ & 0.73 \\
\hline \multirow[t]{2}{*}{$\operatorname{ALT}(\mathrm{U} / \mathrm{L})$} & TÖ** & $35.5(6-281)$ & $27(14-245)$ & 0.20 \\
\hline & $\mathrm{TS}^{* *}$ & $19(8-94)$ & $17(9-72)$ & 0.89 \\
\hline \multirow[t]{2}{*}{ HBV DNA (IU/ml) } & TÖ** & $79537\left(2230-10^{9}\right)$ & $\begin{array}{c}6082 \\
\left(2130-1.4 \times 10^{8}\right)\end{array}$ & 0.11 \\
\hline & $\mathrm{TS}^{* *}$ & $0(0-36)$ & $0(0-0)$ & 0.45 \\
\hline \multirow[t]{2}{*}{ Nekroenflamatuvar skor } & TÖ** & $4(2-11)$ & $4(2-18)$ & 0.55 \\
\hline & $\mathrm{TS}^{* *}$ & $2(0-10)$ & $2(0-6)$ & 0.65 \\
\hline \multirow[t]{2}{*}{ Fibrozis skoru } & TÖ** & $2(1-5)$ & $2(1-3)$ & 0.10 \\
\hline & $\mathrm{TS} * *$ & $2(2-5)$ & $2(2-3)$ & 0.52 \\
\hline
\end{tabular}


Tedavi öncesi HBeAg'si pozitif olan hastaların görülme sıklığı tenofovir grubunda \%21.4 (12/56), entekavir grubunda \%19.4 (6/31) olarak saptanmış, tedavi sonunda bu oran tenofovir grubunda \%14.3 (8/56), entekavir grubunda \%9.7 (3/31) olarak bulunmuştur. Hastaların tedavi öncesi ve sonrası ALT ve HBV DNA değerleri ile modifiye Knodell nekroenflamatuvar skorları ve Ishak fibrozis skorları Tablo I'de gösterilmiştir.

Gruplar arasında, tedavi öncesi ve sonrası ALT ve HBV DNA değerleri ile HAI ve fibrozis skorları açısından istatistiksel olarak anlamlı fark saptanmamıştır ( $p>0.05)$.

Tedavi ile ALT ortanca değeri tenofovir grubunda 35.5 U/L'den 19 U/L'ye, entekavir grubunda $27 \mathrm{U} / \mathrm{L}^{\prime}$ den $17 \mathrm{U} / \mathrm{L}^{\prime}$ ye gerilemiştir. Tedavi sonunda tenofovir grubundaki bir hastada HBV DNA $36 \mathrm{IU} / \mathrm{ml}$ iken, diğer hastaların tümünde ölçülemeyecek düzeyde (negatif) saptanmıştır. Tedavi sonunda, başlangıca göre ALT ve HBV DNA ortanca değerlerindeki azalma her iki grupta istatistiksel olarak anlamlı bulunmuştur $(p<0.001)$ (Tablo I).

Nekroenflamatuvar skorlar ortanca değeri tedavi ile her iki grupta 4'ten 2'ye gerilemişken, Ishak fibrozis skoru ortanca değeri tedavi başlangıcında ve sonunda her iki grupta 2 olarak belirlenmiştir (Tablo I). Nekroenflamatuvar skorda ortalama azalma tenofovir grubunda $2.39 \pm 2.50$, entekavir grubunda $3.77 \pm 3.98$ olarak ve her iki gruptaki azalma istatistiksel olarak anlamlı bulunmuştur $(p<0.001)$. Tedavi sonundaki fibrozis skorlarındaki değişim tenofovir grubunda $0.00 \pm 0.66$, entekavir grubunda $-0.19 \pm 0.65$ olarak bulunmuştur. Tedavi öncesi ve sonundaki fibrozis skorlarındaki değişiklik istatistiksel olarak anlamlı saptanmamıştır ( $p>0.05$ ). Tedavi öncesi ve sonrası nekroenflamatuvar skor ve fibrozis evrelerinin değişimi Şekil 1'de gösterilmiştir.

Tedavi sonunda tenofovir grubunda 37 (\%66.1), entekavir grubunda 17 (\%54.8) toplamda 54 (\%62.1) hastada histolojik yanıt elde edildiği görülmüşsür. Gruplar arasında anlamlı fark bulunmamıştır ( $\mathrm{p}=0.30)$. Nekroenflamatuvar skorda iyileşme tenofovir grubunda 37 (\%66.1), entekavir grubunda 23 (\%74.2) hastada saptanmıştır. Fibrozis skoru tenofovir grubunda hastaların 7 (\%12.5)'sinde iyileşmiş, 8 (\%14.3)'inde kötüleşmiş, 41 (\%73.2)'inde aynı kalmış; entekavir grubunda hastaların 4 (\%12.9)'ünde iyileşmiş, 7 (\%22.6)'sinde kötüleşmiş, 20 (\%64.5)'sinde aynı kalmıştır. Tenofovir ve entekavir grupları arasında nekroenflamatuvar skor ve fibrozis skorunda iyileşme açısından farklılık saptanmamıştır (sırasıyla; $\mathrm{p}=0.43, \mathrm{p}=0.60$ ) (Tablo II).

Çalışmaya tedavi naif ve deneyimli hastaların dahil edilmesinden dolayı, önceki antiviral ilaçların tedavi yanıtlarına etkisini tahmin edebilmek için, hastalar alt gruplara ayrılarak incelenmiştir. Tedavi alt gruplarına göre yapılan değerlendirmede; naif ve deneyimli tenofovir grupları arasında, naif ve deneyimli entekavir grupları arasında, naif tenofovir ve naif entekavir grupları arasında histolojik yanıt açısından farklılık bulunmamıştır (sırasıly; $p=0.93 ; p=0.92$ ve $p=0.48$ ). Tüm hastalar naif ve deneyimli olarak ayrılarak değerlendirildiğinde de histolojik yanıt oranları benzer bulunmuştur ( $p=0.98)$ (Tablo III). Tedavi alt grupları ayrı ayrı incelendiğinde nekroenflamatuvar ve fibrozis skorlarındaki iyileşme oranlarında da istatistiksel olarak anlamlı fark saptanmamıştır ( $p>0.05)$. 


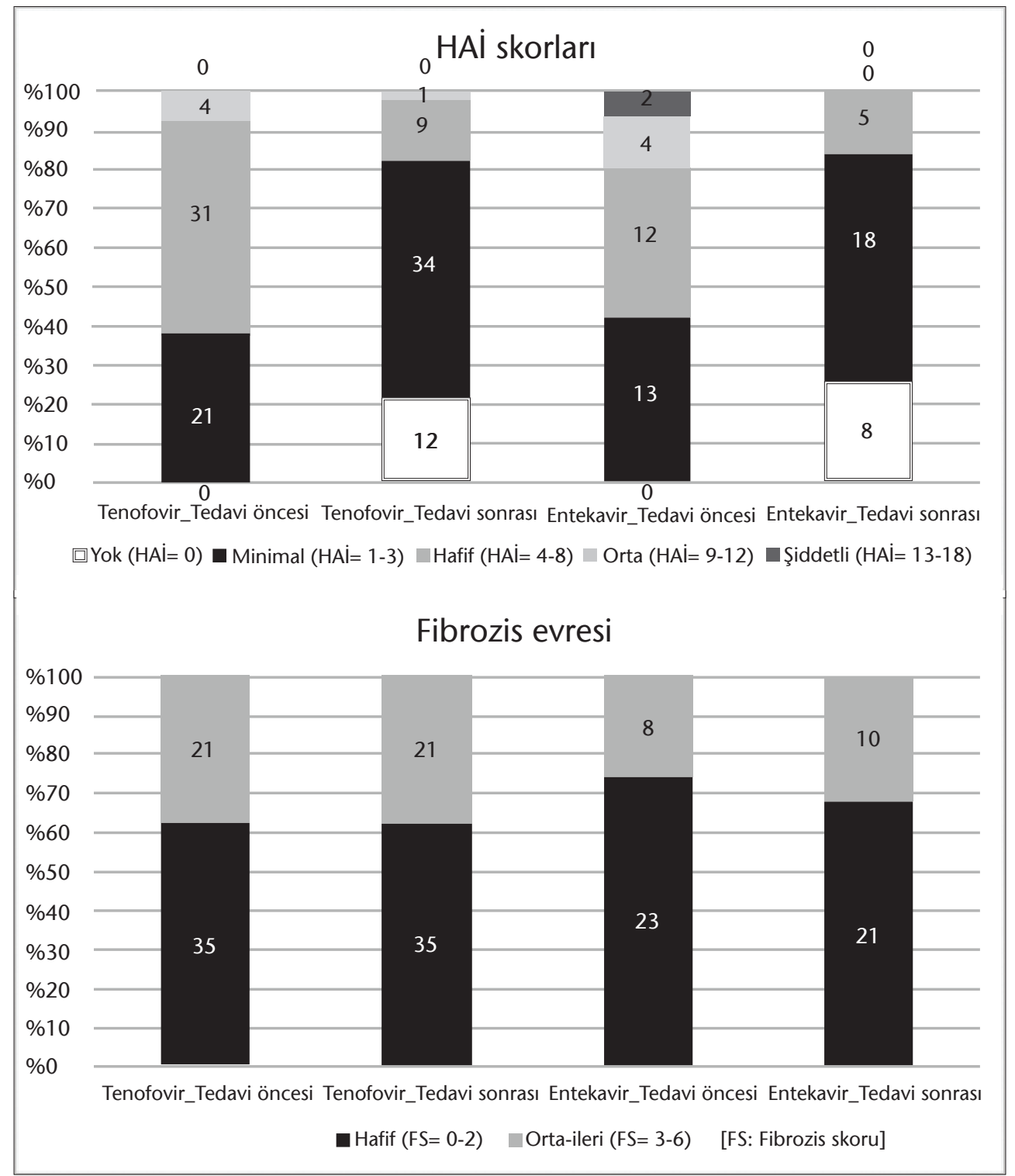

Şekil 1. Tedavi öncesi ve sonrası nekroenflamatuvar skor (HAi) ve fibrozis evreleri (tedavi öncesi).

Tedavi sonrası biyopsi yapıldığı ayda bakılan HBV DNA sonuçlarına göre entekavir kullanan hastaların tümünde, tenofovir kullanan hastaların \%98.2'sinde (55/56) virolojik yanıt elde edilmiştir ( $p>0.05$ ) (Tablo II). Bir hastada başlangıç HBV DNA $2.7 \times 10^{8}$ iken, kontrol biyopsi yapıldığı anda (tedavinin 67. ayında) HBV DNA 36 IU/ml saptanmış ve kısmi virolojik yanıt olarak değerlendirilmiştir. Hastaların virolojik yanıt elde edilme ortanca süreleri tenofovir grubunda üç ay (1-24 ay arasında), entekavir grubunda üç ay (1-36 


\begin{tabular}{|c|c|c|c|}
\hline & $\begin{array}{l}\text { Tenofovir }(n=56) \\
\text { [n veya } n / n(\%)]\end{array}$ & $\begin{array}{l}\text { Entekavir }(\mathrm{n}=31) \\
{[\mathrm{n} \text { veya } \mathrm{n} / \mathrm{n}(\%)]}\end{array}$ & p \\
\hline Histolojik yanıt & $37(66.1)$ & $17(54.8)$ & 0.30 \\
\hline Nekroenflamatuvar skorda iyileşme & $37(66.1)$ & $23(74.2)$ & 0.43 \\
\hline Ishak fibrozis skorunda iyileşme & $7(12.5)$ & $4(12.9)$ & 0.60 \\
\hline Ishak fibrozis skorunda kötüleşme & $8(14.3)$ & $7(22.6)$ & 0.60 \\
\hline Virolojik yanıt & $55(98.2)$ & $31(100)$ & 1.00 \\
\hline Biyokimyasal yanıt ${ }^{a}$ & $18 / 24(75)$ & $5 / 6(83.3)$ & 1.00 \\
\hline HBeAg kaybı ${ }^{b}$ & $4 / 12(33.3)$ & $3 / 6(50)$ & 0.62 \\
\hline HBeAg serokonversiyonu ${ }^{b}$ & $2 / 12(16.7)$ & $2 / 6(33.3)$ & 0.56 \\
\hline HBsAg kaybı & 0 & $1(3.2)$ & * \\
\hline HBsAg serokonversiyonu & 0 & $1(3.2)$ & * \\
\hline
\end{tabular}

\begin{tabular}{|c|c|c|c|c|}
\hline & & \multicolumn{2}{|c|}{ Histolojik yanıt [n (\%)] } & \multirow[b]{2}{*}{$\mathbf{p}$} \\
\hline & & Var & Yok & \\
\hline \multirow[t]{2}{*}{ Tüm hastalar $(n=87)$} & Tenofovir & $37(66.1)$ & $19(33.9)$ & \multirow[t]{2}{*}{0.30} \\
\hline & Entekavir & $17(54.8)$ & $14(45.2)$ & \\
\hline \multirow[t]{2}{*}{ Tüm hastalar $(n=87)$} & Naif & $31(62)$ & $19(38)$ & \multirow[t]{2}{*}{0.98} \\
\hline & Deneyimli & $23(62.2)$ & $14(37.8)$ & \\
\hline \multirow[t]{2}{*}{ Tenofovir $(n=56)$} & Naif & $21(65.6)$ & $11(34.4)$ & \multirow[t]{2}{*}{0.93} \\
\hline & Deneyimli & $16(66.7)$ & $8(33.3)$ & \\
\hline \multirow[t]{2}{*}{ Entekavir $(\mathrm{n}=31)$} & Naif & $10(55.6)$ & $8(44.4)$ & \multirow[t]{2}{*}{0.92} \\
\hline & Deneyimli & $7(53.8)$ & $6(46.2)$ & \\
\hline \multirow[t]{2}{*}{ Naif hastalar $(n=50)$} & Tenofovir & $21(65.6)$ & $11(34.4)$ & \multirow[t]{2}{*}{0.48} \\
\hline & Entekavir & $10(55.6)$ & $8(44.4)$ & \\
\hline
\end{tabular}

ay arasında) olarak saptanmıştır. Gruplar arasında virolojik yanıt sağlanma süresi ortalaması açısından istatistiksel olarak anlamlı fark saptanmamıştır ( $p=0.12)$. Her iki tedavi grubunda virolojik kırılma görülmemiş̧tir.

Tedavi öncesi HBeAg pozitif olan tenofovir grubunda 12 hasta, entekavir grubunda ise altı hasta mevcutken tedavi sonunda tenofovir grubunda 4 (\%33.3), entekavir grubunda 3 (\%50) hastada HBeAg kaybı geliştiği görülmüştür. HBeAg serokonversiyonu 
gelişen hasta sayısı tenofovir grubunda 2 (\%16.7), entekavir grubunda 2 (\%33.3) olarak belirlenmiştir. Gruplar arasında HBeAg kaybı ve serokonversiyonu açısından istatistiksel olarak anlamlı fark saptanmamıştır (sırasıyla; $p=0.62, p=0.56$ ) (Tablo II).

Entekavir grubunda HBsAg kaybı ve serokonversiyonu gelişen 1 (\%3.2) hasta mevcutken tedavi başlangıcında HBeAg negatif; telbivudin deneyimli, entekavir tedavisi almakta olan hastanın toplam tedavisinin 48. ayında HBsAg kaybı ve serokonversiyonu sağlandığı görülmüştür. Hasta sayısı yeterli olmadığı için istatistiksel değerlendirme yapılmamıştır (Tablo II).

Tedavi öncesi ALT yüksekliği bulunan hastalarda, ALT normalizasyonu (< 1 NÜS); tenofovir grubunda \%75 (18/24), entekavir grubunda \%83.3 (5/6) oranında sağlanmıştır. Gruplar arasında biyokimyasal yanıt açısından istatistiksel olarak anlamlı fark saptanmamıştır ( $p=1.00)$ (Tablo II).

Hastalar tedaviye yanıtı etkileyebileceği düşünülen yaş, tedavi süresi, başlangıç ALT ve HBV DNA değeri ile başlangıç nekroenflamatuvar skor ve fibrozis skoru gibi değişkenlere göre gruplandırılarak değerlendirilmiştir. Tedavi başlangıcında fibrozis evresi orta-ileri evre (fibrozis skoru 3-6) olanlarda histolojik yanıt, nekroenflamatuvar skorda iyileşme ve fibrozis skorunda iyileşme, fibrozis evresi hafif (fibrozis skoru: 1-2) olanlara göre anlamlı olarak daha yüksek bulunmuştur (sırasıyla; $p=0.005, p=0.049, p=0.000$ ). Tedavi süresi beş yıldan uzun olanlarda nekroenflamatuvar skorda iyileşme daha yüksek tespit edilmiştir $(p=0.014)$. Araştırılan diğer değişkenlerde histolojik yanıt, nekroenflamatuvar skorda ve fibrozis skorunda iyileşme açısından anlamlı fark saptanmamıştır ( $p>$ 0.05) (Tablo IV).

Tenofovir ve entekavir alan hastalar ayrı ayrı değerlendirildiğinde; tenofovir grubunda fibrozis evresi orta-ileri olanlarda fibrozis skorunda iyileşme anlamlı olarak daha yüksek bulunmuştur $(\mathrm{p}=0.000)$. Entekavir grubunda fibrozis evresi orta-ileri olanlarda histolojik yanıt ve fibrozis skorunda iyileşme daha yüksek saptanmıştır (sırasıyla $p=$ $0.045, \mathrm{p}=0.043$ ). Tedavi naif hastalarda fibrozis skoru orta-ileri evre olanlarda histolojik yanıt, nekroenflamatuvar skor ve fibrozis skorunda iyileşme oranları daha yüksek bulunmuştur (sırasıyla; $\mathrm{p}=0.001, \mathrm{p}=0.004, \mathrm{p}=0.04$ ). Yine bu grupta tedavi başlangıcındaki HBV DNA değeri > $20000 \mathrm{IU} / \mathrm{ml}$ olanlarda nekroenflamatuvar skorda iyileşme oranı daha yüksek ( $p=0.027$ ) saptanırken, tedavi deneyimli hastalarda fibrozis evresi ortaileri olanlarda, fibrozis skorunda iyileşme oranları daha yüksek bulunmuştur $(p=0.000)$.

Tedavi yanıtlarını etkileyen faktörleri araştırmak için yapılan regresyon analizinde; fibrozis evresinin orta-ileri olması, histolojik yanıt sağlanmasında ve fibrozis skorunda iyileşmede bağımsız belirleyici faktör olarak bulunmuştur (sırasıyla OR=3.99, p=0.01; $\mathrm{OR}=31.67, \mathrm{p}=0.002)$. Tedavi süresinin beş yıldan uzun olması nekroenflamatuvar skorda iyileşme için bağımsız belirleyici faktör olarak bulunmuştur ( $O R=5.79, p=0.02)$. 


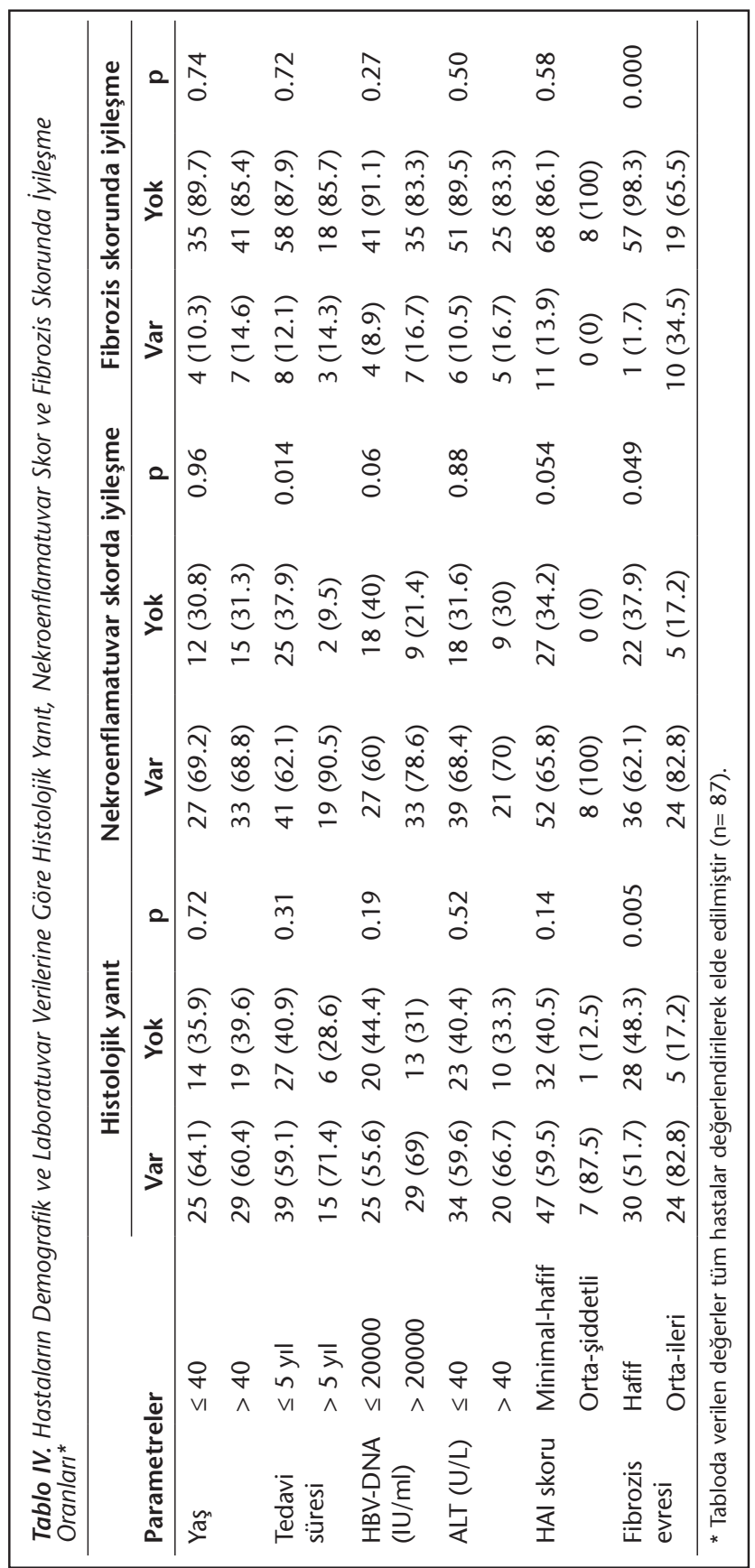




\section{TARTIŞMA}

HBV replikasyon düzeyinin, hastalık progresyonu ve kronik HBV enfeksiyonunun uzun dönem sonuçları ile güçlü ilişkili olduğu bildirilmektedir ${ }^{5}$. Yirmi altı prospektif çalışmanın yer aldığı bir derlemede, viral yük seviyesi veya değişimi ile histolojik derecelendirme, biyokimyasal ve serolojik yanıt arasında istatistiksel olarak anlamlı ve tutarlı korelasyon bulunmuştur ${ }^{14}$. Antiviral tedavi ile viral replikasyon inhibisyonunun, hastaların büyük çoğunluğunda kronik HBV ile indüklenen nekroenflamatuvar aktivitenin ve progresif karaciğer hasarının eliminasyonunu başardığı ve HSK riskini azalttığı gösterilmiştir ${ }^{5}$.

Yapılan çalışmalarda antiviral tedavi ile KHB hastalarında histolojik bulgularda iyileşme ve fibroziste gerileme olabileceği belirtilmiştir ${ }^{11,15-19}$. Literatür incelendiğinde; antiviral tedavi ile histolojik yanıt oranları açısından farklı sonuçlar bildirilmiştir. Farklı oral antiviral ilaçlar ile METAVIR skorlama sistemine göre hastalarda \%72 oranında histolojik iyileşme gösterilmiştir ${ }^{20}$. Histolojik yanıt oranları entekavir tedavisi ile \%55-100 aralığın$\mathrm{da}^{10,16,17,21-24}$; tenofovir tedavisi ile \%71.1-87 aralığında bildirilmiştir ${ }^{11,25,26}$. Çalışmamızda tenofovir grubunda \%66.1 (37/56); entekavir grubunda \%54.8 (17/31) ve tüm hastalarda \%62 (54/87) oranında histolojik yanıt sağlandığı görülmüştür.

Nekroenflamatuvar skorda iyileşme tenofovir grubunda 37 (\%66.1), entekavir grubunda 23 (\%74.2) hastada sağlanmıştır. Köse ve arkadaşları yaptıkları çalışmada9 ${ }^{9}$, entekavir tedavisi ile \%50 oranında, Marcellin ve arkadaşları ise ${ }^{25}$ tenofovir tedavisi ile \%78 oranında nekroenflamatuvar skorda iyileşme bildirmişlerdir.

Fibrozis skoru tenofovir grubundaki hastaların 7 (\%12.5)'sinde azalmış, 8 (\%14.3)'inde artmış; entekavir grubundaki hastaların 4 (\%12.9)'ünde azalmış, 7 (\%22.6)'sinde artmıştır. Farklı yayınlarda entekavir tedavisi ile fibroziste iyileşme \%30.4-39 oranında, fibroziste kötüleşme \%2-11 oranında bildirilmiştir ${ }^{9,22-24}$. Yokosuka ve arkadaşlarının yaptıkları çaış̧mada ${ }^{10}$ üç yıl entekavir tedavisi alan 21 hastanın \%57'sinde fibrozis skorlarında gerileme saptanmıştır. Başka bir çalışmada da entekavir tedavisi ile 48. haftada \%32 oranında fibroziste iyileşme sağlanırken, uzun dönem sonunda (ortalama altı yıl) bu oran \%88'e çıkmış; histolojik yanıt oranları da sırasıyla $\% 73$ ve $\% 96$ olarak bildirilmiştir ${ }^{17}$. Bu sonuçlar, tedavi süreleri ile histolojik yanıt ve fibrozis skorlarında iyileşme oranları arasında doğru orantı olduğunu düşündürmektedir. Çalışmamızda da tedavi süresi beş yıldan uzun olanlarda nekroenflamatuvar skorda iyileşme daha yüksek saptanmıştır. Tedavi süresinin beş yıldan uzun olması, nekroenflamatuvar skorda iyileşme için bağımsız belirleyici faktör olarak bulunmuştur.

Literatürde ileri evre fibrozis/sirozu bulunanlarda yüksek histolojik yanıt ve fibroziste gerileme oranları bildiren çalışmalar mevcuttur. Beş yıl tenofovir tedavisi alan hastalarla yapılan bir çalışmada, fibrozis skorunda gerileme hastaların \%51'inde görülürken; tedavi öncesi Ishak fibrozis skoru 5 ve 6 olanlarda bu oranın \%74'e çıktığı, yine Ishak fibrozis skoru > 2 olanlarda histolojik iyileşmenin \%91'in üzerinde olduğu belirtilmiştir ${ }^{11}$. Schiff ve arkadaşlarının yaptıkları çalışmada ${ }^{16}$, uzun süreli entekavir tedavisi alan, ilerlemiş fibrozisi 
(Ishak fibrozis skoru $\geq 4$ ) olan 10 hastanın; uzun dönem tedavi sonunda (ortalama 288 hafta) tümünde histolojik iyileşme ve fibrozis skorunda iyileşme görülmüştür. Buti ve arkadaşlarının yaptıkları çalışmada ${ }^{27}$ ise beş yıl tenofovir tedavisi sonunda Knodell skorunda iyileşme ( $\geq 1$ puan azalma) sirotik hastalarda \%93.8, nonsirotik hastalarda \%90.8 oranında bulunmuş, gruplar arasında fark saptanmamıştır. Siroz varlığından bağımsız olarak tenofovir tedavisi ile benzer histolojik yanıt sağlandığı belirtilmiştir. Çalışmamızda, tedavi başlangıcında fibrozis evresi orta-ileri evre (fibrozis skoru: 3-6) olanlarda histolojik yanıt, nekroenflamatuvar skorda iyileşme ve fibrozis skorunda iyileşme anlamlı olarak daha yüksek saptanmıştır. Fibrozis evresinin orta-ileri olması, histolojik yanıt sağlanmasında ve fibrozis skorunda iyileşmede bağımsız belirleyici faktör olarak belirlenmiştir. Sunduğumuz çalışmada fibroziste iyileşme oranlarının, diğer çalışmalarda belirtilen iyileşme oranlarından göreceli olarak düşük saptanmasının nedeni; tedavi başlangıcında fibrozis evresi orta-ileri olan hastaların daha az sayıda olmasından kaynaklanabilir.

Çalışmamızda elde edilen verilere benzer şekilde histolojik yanıt ve fibrozis skorunda iyileşmenin belirleyici faktörlerini araştıran az sayıda çalışma mevcuttur. Papachrysos ve arkadaşlarının çalışmasında ${ }^{19}$ fibroziste iyileşmenin belirleyici faktörleriyle tedavi süreleri arasında fark saptanmamış; fibroziste iyileşme sağlanan hastalarda başlangıç ALT ve AST düzeyleri daha düşük olmasına rağmen bu durum istatistiksel olarak anlamlı bulunmamıştır. Sherman ve arkadaşları ${ }^{23}$, başlangıç HBV DNA düzeyleri ile histolojik yanıt arasında ilişki saptamamışlardır. Başlangıç ALT düzeyi $<2 \times$ NÜS'ten, $>5$ x NÜS'e arttığında histolojik yanıt ve virolojik yanıt oranlarının arttığını, biyokimyasal yanıt oranlarının azaldığını bildirmişlerdir. Sunduğumuz çalışmada başlangıç ALT düzeyleri ile histolojik yanıt, nekroenflamatuvar skor ve fibrozis skorlarında azalma arasında ilişki saptanmamıştır. Tedavi naif hastalarda, tedavi başlangıcındaki HBV DNA değeri > $20000 \mathrm{IU} / \mathrm{ml}$ olanlarda nekroenflamatuvar skorda iyileşme oranı daha yüksek belirlenmiş̧tir. Ancak, diğer gruplarda başlangıç HBV DNA değerleri ile histolojik yanıtlar, HAi ve fibrozis skorlarındaki iyileşme arasında anlamlı ilişki saptanmamıştır.

Çalışmamıza dahil edilen tedavi deneyimli hastaların önceki tedavilerinin sonuçlara etkisini tahmin edebilmek için, tedavi naif ve deneyimli hastaların gruplandırılarak yapılan değerlendirmelerinde benzer tedavi yanıtları saptanmıştır. Potent antiviral ilaçlarla daha yüksek histolojik yanıt sağlandığını belirten yayınlar mevcuttur ${ }^{22,23,28}$. Papachrysos ve arkadaşlarının çalışmasında ${ }^{20}$, virolojik kırılma saptanan hastalara ikinci bir antiviral ilaç ile erken kurtarma sağlandığında, fibrozis gerilemesinin engellenmediği belirtilmiştir. Sunduğumuz çalışma; hastaların çoğunda önceki tedaviler ile viral replikasyonun baskılanması ve histolojik yanıtlarda fark saptanmaması nedeniyle Papachrysos ve arkadaşlarının çalışmasıyla uyumludur.

Çalışmamızda potent antiviral ilaçlar olan tenofovir ve entekavir ile tedavi sonunda yüksek virolojik yanıt sağlanmıştır. Gerçek yaşam verilerini içeren bir derlemede; virolojik yanıt oranları entekavir için \%76-96 arasında; tenofovir için \%71-92 arasında bildirilmiştir $^{29}$. Entekavir ve tenofovirin karşılaştırıldığı bir çalışmada ${ }^{32}$ benzer virolojik yanıt 
oranları saptanırken, başka bir çalışmada ${ }^{31} 48$. hafta virolojik yanıtları entekavir grubunda $\% 86.4$, tenofovir grubunda \%96.7 bulunmuş; tenofovir grubundaki yükseklik istatistiksel olarak anlamlı bulunmamıştır. Ceylan ve arkadaşlarının tenofovir ve entekavir tedavilerini karşılaştırdıkları çalışmada ${ }^{32}$, tenofovir kullanan hastalarda virolojik yanıtın daha yüksek olduğu saptanmıştır. Literatürle uyumlu olarak her iki grupta benzer oranda ALT normalizasyonu sağlanmıştır ${ }^{33-35}$.

Gerçek yaşam verileri ile yapılan bir derlemede HBeAg serokonversiyonu entekavir grubunda \%8-53 oranında, tenofovir grubunda \%7-18.3 oranında verilmiştir ${ }^{29}$. Sunduğumuz çalışmada tedavi sonunda HBeAg kaybı ve serokonversiyonu, sırasıyla tenofovir grubunda \%33.3 ve \%16.7; entekavir grubunda \%50 ve \%33 oranında sağlanmıştır. Sonuçlarımıza göre tedavi gruplarında benzer serolojik yanıt bulunmuştur, ancak başka bir çalışmada tedavinin birinci yılında HBeAg serokonversiyonu sağlanması açısından en etkin antiviral ilacın tenofovir olduğu belirtilmiştir ${ }^{27}$. Pol ve arkadaşlarının derlemesinde ${ }^{29}$ HBsAg kaybı, entekavir grubunda \%0.5-10, tenofovir grubunda \%0-2.3 arasında bildirilmiştir. Bu derlemede bildirildiği gibi, tedavide ideal sonlanım noktası olan HBsAg kaybı ve/veya serokonversiyonu, KHB hastalarında düşük oranlarda gözlenmektedir. Sunduğumuz çalışmada, entekavir grubunda 1 (\%3.2) hastada HBsAg kaybı ve serokonversiyonu geliştiği saptanmıştır.

Çalışmamızda iki potent antiviral ilaç olan tenofovir veya entekavir tedavisi alan KHB hastalarında; antiviral tedavi ile benzer histolojik, virolojik, serolojik ve biyokimyasal yanıt elde edildiği tespit edilmiştir. Güzelbulut ve arkadaşlarının çalışmasında ${ }^{35} \mathrm{da}$, nükleoz(t)itnaif KHB hastalarında 48 hafta tedavi sonunda tenofovir ve entekavir ile benzer histolojik, virolojik ve biyokimyasal yanıt sağlandığı belirtilmiştir. Tedavi deneyimli hastaların dahil edilmesi ve histolojik yanıtlara etkileyen faktörlerin araştırılması ile çalışmamız literatürden farklılık göstermektedir.

Çalışmamızın kısıtlılığı; tedavi deneyimli hastalara, tedavi değişikliği yapıldığı anda karaciğer biyopsilerinin yapılamamış olmasıdır. Bunun sonucu olarak, bu hastalarda daha önce kullanılan tedavilerin histopatolojiye etkileri değerlendirilememiştir. Ancak naif ve deneyimli hastalar ayrı ayrı değerlendirilerek, daha önce kullanılan tedavilerin, histolojik yanıtlara etkisinin olup olmadığı araştırılmış; tedavi deneyimli ve naif hastalar arasında histolojik yanıt sağlanması açısından fark saptanmamıştır.

Sonuç olarak, KHB hastalarında tenofovir ve entekavir tedavileri ile benzer histolojik, virolojik, serolojik ve biyokimyasal yanıt elde edilmiştir. Etkili tedavi ile uzun dönem viral supresyon ve histolojik iyileşme sağlanabilmektedir. Antiviral tedavilerin karaciğer histolojisindeki iyileşmeye etkilerinin anlaşılabilmesi için uzun süreli tedavi alan, daha fazla hasta sayısı ile yapılacak çalışmaların yararlı olacağı düşüncesindeyiz.

\section{ÇIKAR ÇATIŞMASI}

Yazarlar bu makale ile ilgili herhangi bir çıkar çatışması bildirmemişlerdir. 
Tenofovir veya Entekavir Tedavisi Alan Kronik Hepatit B Hastalarında Histolojik Yanıtların Değerlendirilmesi

\section{KAYNAKLAR}

1. World Health Organization. Guidelines for the Prevention Care and Treatment of Persons with Chronic Hepatitis B Infection: Mar-15. World Health Organization, 2015.

2. Iloeje UH, Yang HI, Su J, Jen CL, You SL, Chen CJ. Predicting cirrhosis risk based on the level of circulating hepatitis B viral load. Gastroenterology 2006;130(3):678-86.

3. Chen CJ, Yang HI, Su J, Jen CL, You SL, Lu SN, et al. Risk of hepatocellular carcinoma across a biological gradient of serum hepatitis B virus DNA level. JAMA 2006;295(1):65-73.

4. Sarin SK, Kumar M, Lau GK, Abbas Z, Chan HL, Chen CJ, et al. Asian-Pacific clinical practice guidelines on the management of hepatitis B: a 2015 update. Hepatology Int 2016;10(1):1-98.

5. European Association for The Study of The Liver. EASL 2017 Clinical Practice Guidelines on the management of hepatitis B virus infection. J Hepatol 2017;67(2):370-98.

6. Terrault NA, Bzowej NH, Chang KM, Hwang JP, Jonas MM, Murad MH, et al. AASLD guidelines for treatment of chronic hepatitis B. Hepatology 2016;63(1):261-83.

7. Tong MJ, Kowdley KV, Pan C, Hu KQ, Chang TT, Han KH, et al. Improvement in liver histology among Asian patients with chronic hepatitis B after long-term treatment with entecavir. Liver Int 2013;33(4):650-1.

8. Wang JL, Du XF, Chen SL, Yu YQ, Wang J, Hu XQ, et al. Histological outcome for chronic hepatitis B patients treated with entecavir vs. lamivudine-based therapy. World J Gastroentrol 2015;21(32):9598-606.

9. Kose S, Tatar B, Gül S, Pala E. The effect of long-term entecavir therapy on liver histopathology in patients with chronic viral hepatitis B. Acta Clinica Belgica 2016;71(4):244-9.

10. Yokosuka O, Takaguchi K, Fujioka S, Shindo M, Chayama K, Kobashi H, et al. Long-term use of entecavir in nucleoside-naive Japanese patients with chronic hepatitis B infection. J Hepatol 2010;52(6):791-9.

11. Marcellin P, Gane Buti M, Afdhal N, Sievert W, Jacobson IM, Washington MK, et al. Regression of cirrhosis during treatment with tenofovir disoproxil fumarate for chronic hepatitis B: a 5-year open-label follow-up study. Lancet 2013;381(9865):468-75.

12. Boettler T, Thimme R. Antiviral therapy in hepatitis B virus-associated liver cirrhosis. Dig Dis 2015;33(4):60812.

13. Artus HBV PCR kits. Available from https://www.qiagen.com/gb/products/diagnostics-and-clinicalresearch/transplant/artus-viral-load/artus-hbv-pcr-kits-ce/clear=true.

14. Marin HM, Mondou E, Blum MR, Rousseau F. Serum HBV DNA as a marker of efficacy during therapy for chronic HBV infection: analysis and review of the literature. Hepatology 2003;37(6):1309-19.

15. Dienstag JL, Goldin RD, Heathcote EJ, Hann HW, Woessner M, Stephenson SL, et al. Histological outcome during long-term lamivudine therapy. Gastroenterology 2003;124(1):105-17.

16. Schiff ER, Lee SS, Chao YC, Kew Yoon S, Bessone F, Wu SS, et al. Long-term treatment with entecavir induces reversal of advanced fibrosis or cirrhosis in patients with chronic hepatitis $\mathrm{B}$. Clin Gastroenterol Hepatol 2011;9(3):274-6.

17. Chang TT, Liaw YF, Wu SS, Schiff E, Han KH, Lai CL, et al. Long-term entecavir therapy results in the reversal of fibrosis/cirrhosis and continued histological improvement in patients with chronic hepatitis $\mathrm{B}$. Hepatology 2010;52(3):886-93.

18. Ganem D, Prince AM. Hepatitis B virus infection-natural history and clinical consequences. N Engl J Med 2004;350(11):1118-29.

19. Bedossa P. Reversibility of hepatitis B virus cirrhosis after therapy: who and why? Liver Int 2015;35:78-81.

20. Papachrysos N, Hytiroglou P, Papalavrentios L, Sinakos E, Kouvelis L, Akriviadis E. Antiviral therapy leads to histological improvement of HBeAg-negative chronic hepatitis B patients. Ann Gastroenterol 2015;28(3):374-8.

21. Matthews SJ. Entecavir for the treatment of chronic hepatitis B virus infection. Clin Ther 2006;28(2):184203. 
22. Chang TT, Gish RG, de Man R, Gadano A, Sollano J, Chao YC, et al. A comparison of entecavir and lamivudine for HBeAg-positive chronic hepatitis B. N Engl J Med 2006;354(10):1001-10.

23. Lai CL, Shouval D, Lok AS, Chang TT, Cheinquer H, Goodman Z, et al. Entecavir versus lamivudine for patients with HBeAg-negative chronic hepatitis B. N IJ Med 2006;354(10):1011-20.

24. Sherman M, Yurdaydin C, Sollano J, Silva M, Liaw YF, Cianciara J, et al. Entecavir for treatment of lamivudinerefractory, HBeAg-positive chronic hepatitis B. Gastroenterology 2006;130(7):2039-49.

25. Marcellin P, Heathcote EJ, Buti M, Gane E, de Man RA, Krastev Z, et al. Tenofovir disoproxil fumarate versus adefovir dipivoxil for chronic hepatitis B. N Engl J Med 2008;359(23):2442-55.

26. Hou JL, Gao ZL, Xie Q, Zhang JM, Sheng JF, Cheng J, et al. Tenofovir disoproxil fumarate vs adefovir dipivoxil in Chinese patients with chronic hepatitis B after 48 weeks: a randomized controlled trial. J Viral Hepat 2015;22(2):85-93.

27. Buti M, Fung S, Gane E, Afdhal NH, Flisiak R, Gurel S, et al. Long-term clinical outcomes in cirrhotic chronic hepatitis B patients treated with tenofovir disoproxil fumarate for up to 5 years. Hepatol Int 2015;9(2):24350.

28. Woo G, Tomlinson G, Nishikawa Y, Kowgier M, Sherman M, Wong DK, et al. Tenofovir and entecavir are the most effective antiviral agents for chronic hepatitis B: a systematic review and Bayesian meta-analyses. Gastroenterology 2010;139(4):1218-29.

29. Pol S, Lampertico P. First-line treatment of chronic hepatitis B with entecavir or tenofovir in 'real-life'settings: from clinical trials to clinical practice. J Viral Hepat 2012;19(6):377-86.

30. Wu IT, Hu TH, Hung CH, Lu SN, Wang JH, Lee CM, et al. Comparison of the efficacy and safety of entecavir and tenofovir in nucleos ( $\mathrm{t}$ ) ide analogue-naive chronic hepatitis $\mathrm{B}$ patients with high viraemia: a retrospective cohort study. Clin Microbiol Infect 2017;23(7):464-9.

31. Shi H, Huang M, Lin G, Li X, Wu Y, Jie Y, et al. Efficacy comparison of tenofovir and entecavir in HBeAgpositive chronic hepatitis B patients with high HBV DNA. Biomed Res Int 2016;2016:6725073.

32. Ceylan B, Yardımcı C, Fincancı M, Eren G, Tozalgan U, Muderrisoglu C, et al. Comparison of tenofovir and entecavir in patients with chronic HBV infection. Eur Rev Med Pharmacol Sci 2013;17(18):2467-73.

33. Park JW, Kwak KM, Kim SE, Jang MK, Suk KT, Kim DJ, et al. Comparison of the long-term efficacy between entecavir and tenofovir in treatment-naïve chronic hepatitis B patients. BMC Gastroenterol 2017;17(1):39.

34. Batirel A, Guclu E, Arslan F, Kocak F, Karabay O, Ozer S, et al. Comparable efficacy of tenofovir versus entecavir and predictors of response in treatment-naïve patients with chronic hepatitis $\mathrm{B}$ : a multicenter reallife study. Int J Infect Dis 2014;28:153-9.

35. Güzelbulut F, Ovünç AO, Cetinkaya ZA, Senates E, Gökden Y, Saltürk AG, et al. Comparison of the efficacy of entecavir and tenofovir in chronic hepatitis B. Hepatogastroenterology 2012;59(114):477-80. 